\title{
New Tubular Type SOFC Using Metallic System Components
}

\author{
Takayasu OKUO*, Yasuo KAGA and Akihiko MOMMA
}

Received December 19, 1995 ; Accepted February 7, 1996

\begin{abstract}
The authers have established a new design for tubular type Solid 0xide Fuel Cells at substantially lower cost with high power density, based on a porous metallic tubular substrate produced by flame coating. The electrolyte layer is prepared by atmospheric plasma spray coating and densified by surface treatment with inexpensive chemical densification.
\end{abstract}

\section{INTRODUCTION}

Investigation of several cell designs has been made to undertaken by various researchers to achieve maximum power with durability. The best results have been obtained by variation in tubular configuration. The Fully Bar Anode type of Mestinghouse ${ }^{1 "}$ and segmented type of Mitsubishi lleavy Industries ${ }^{2)}$ have longer life cycles and stability of power.

The authors have proposed ${ }^{3)}$ several metallic systems of the tubular type SOFC for tubular substrates, electrodes and interconnectors. A less costly produced porous tubular substrate made of these materials showed good compatibility with YSZ electrolyte under surplus heat shock in the spray coating and long time heat treatment under atmospheric high temperature conditions". By spray coating of SOFC components, single cells consisting of metallic tubular substrate were produced and operated.

\section{EXPERIMENTAL}

\section{1 Materials and processing}

One objective have been carried out a metallic tubular substrate multi-cell stack configuration using atmospheric plasma spray (APS) coating and gas flame spray coating, in consideration of the

Electrotechnical Laboratory

(1-1-4 Umezono, Tsukuba-shi, Ibaraki 305, Japan)

Key Words : Metallic substrate, APS coating. Sealing treatment, Duration test following : (1) A metallic tubular substrate is less expensive compared with the $\mathrm{ZrO}_{2}-\mathrm{CaO}$ ( $\mathrm{CSZ}$ ) or $\mathrm{LaSrHnO}_{3}$ (LSH) ceramic substrate tube and has greater durability against thermal shock in high enthalpy plasma coating. (2) APS coating is not costly or complex. The APS coating built in automatic fabrication system can be easily made through there either disadvantage that completely gas tight YSZ film can not made.

The materials and processing are shown in Table 1.

\section{2 Densification of electrolytes}

A 7 mol\% $\mathrm{Y}_{2} \mathrm{O}_{3}$ stabilized zirconia (7YSZ) film was made using the APS coating system on a meta11 ic tubular substrate $18 \mathrm{~mm}$ in outer diameter, $100 \mathrm{~mm}$ in length and about $500 \mu \mathrm{m}$ in thickness. Following formation of the YSZ film of thickness ranging from 80 to $220 \mu \mathrm{m}$, sealing treatment was carried out on the YSZ surface as follows. An organic metal solution of yttrium and zirconium was brush-painted on the surface of APS deposited YSZ. The inside of the tube was vacuum pumped by Hitachi direct drive rotary pump (type-160VP-D/ $1741 /$ min). The sample was then heated to $700^{\circ} \mathrm{C}$ at a rate of $100^{\circ} \mathrm{C} / \mathrm{hr}$ and kept for 1 hour at this temperature. To assess gas tightness of the treated film, the inside of the tube was vacuum pumped and balanced vacuum level $\left(\mathrm{P}_{\mathrm{b}}\right)$ which is a measure of gas impermeability was recorded ${ }^{5)}$. This process was repeated 3 to 7 times until satisfactory film was obtained.

The densification curves are shown in Fig. 1. The 3 -cycle treatment improves the impermeability of 
Table 1 Materials and processing for new tubular type SOFC.

\begin{tabular}{|c|c|c|c|c|c|c|c|}
\hline No. & \multicolumn{2}{|l|}{ COMPONENT } & MATERIAL & $\begin{array}{l}\text { PRODUCTION } \\
\text { METHOD }\end{array}$ & $\begin{array}{l}\text { THICK- } \\
\text { MESS } \\
(\mu \mathrm{m})\end{array}$ & $\begin{array}{l}\text { CONDUC- } \\
\text { TiVITY } \\
(\mathrm{S} / \mathrm{cm})\end{array}$ & $\begin{array}{l}\text { FIL CONPOSITION } \\
\text { CHARACTER }\end{array}$ \\
\hline 1 & \multicolumn{2}{|l|}{$\begin{array}{l}\text { EDGE LEAD } \\
\text { CONMECTOR }\end{array}$} & N10 & $\begin{array}{l}\text { PLASHA } \\
\text { COATING }\end{array}$ & 200 & 1,150 & $\begin{array}{l}\text { NiCr22A110YI ALLOY } \\
\text { HIGH DEMSITY FILH }\end{array}$ \\
\hline 2 & \multicolumn{2}{|c|}{$\begin{array}{l}\text { POROUS METALLIC } \\
\text { AMODE }\end{array}$} & $\mathrm{Ni} / \mathrm{N} 10$ & $\begin{array}{l}\text { FLAME } \\
\text { COATING }\end{array}$ & $\begin{array}{l}4501 \\
50\end{array}$ & 39.000 & $\begin{array}{l}\text { Mi N10 LAMINATEO } \\
\text { POROUS FILL }\end{array}$ \\
\hline \multirow[t]{2}{*}{3} & \multirow{2}{*}{$\begin{array}{l}\text { AMODE } \\
\text { ACTIVATOR }\end{array}$} & $3 \mathbf{a}$ & $N i-Y$ & $\begin{array}{l}\text { SLURRY } \\
\text { COATIMG }\end{array}$ & $30-$ & & BAKING POROUS FILU \\
\hline & & $3 b$ & NiOt7YSZ2O & $\begin{array}{l}\text { FLAMEE } \\
\text { COATING }\end{array}$ & 100 & 1.050 & CERUET POROUS FILU \\
\hline 4 & \multicolumn{2}{|c|}{$\begin{array}{l}\text { ELECTROLYTE } \\
\text { (SEAL ING TREATUENT) }\end{array}$} & $\begin{array}{l}7 Y S Z \\
(Y \& 2 r)\end{array}$ & $\begin{array}{l}\text { PLASWA } \\
\text { COATING }\end{array}$ & $\begin{array}{l}100^{-} \\
200^{-}\end{array}$ & 0.06 & $\begin{array}{l}\text { Zro2-7molXY203 } \\
\text { HIGH DEMSITY FILU }\end{array}$ \\
\hline 5 & \multicolumn{2}{|l|}{ CATHODE } & LSII & $\begin{array}{l}\text { FLAME } \\
\text { COATINO }\end{array}$ & 100 & 15 & LaSrIMn03 POROUS FILI \\
\hline
\end{tabular}

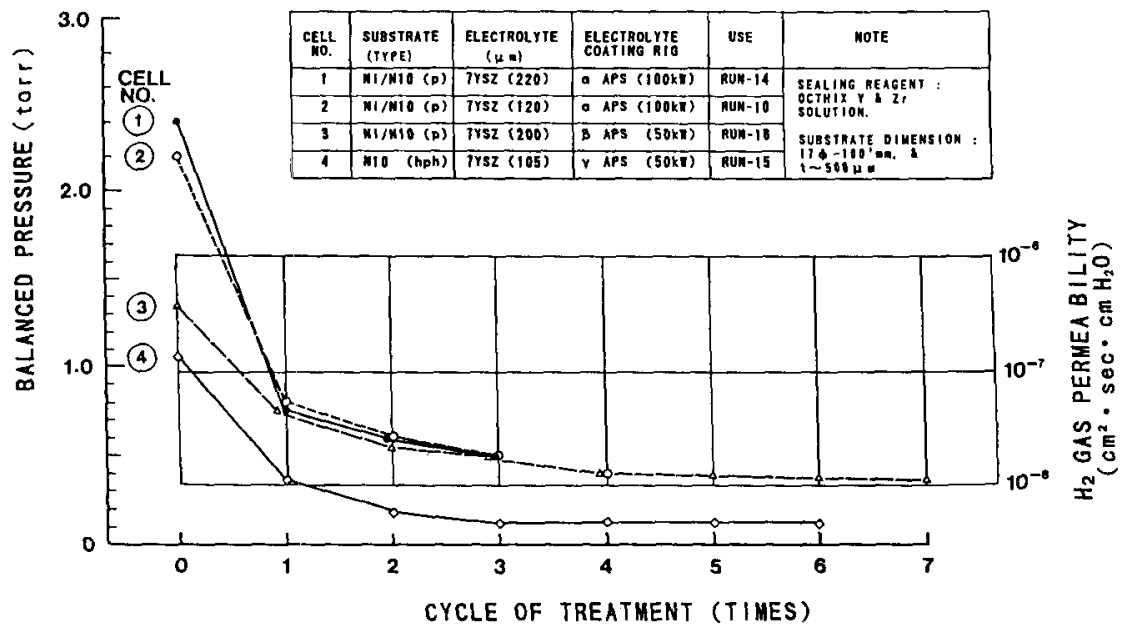

Fig. 1 Effect of sealing treatment on permeability of YSZ films prepared by APS coating.

hydrogen up to about $10^{-8}\left(\mathrm{~cm}^{2} / \mathrm{sec} \cdot \mathrm{cmH}_{2} \mathrm{O}\right)$, this making possible sufficient open circuit voltage (OCV).

\section{3 Configuration and fabrication}

Figure 2 shows a single cell configuration made almost completely by spray coating. The p-type metallic substrate is a porous cylindrical thin tube consisting of a Ni/N10 laminated highly electronically conductive layer. It was prepared by flame coating on an aluminum tube which was removed by chemical dissolution.

An anode $\mathrm{Ni}-\mathrm{Y}$ activation layer laminated on the N10 substrate was prepared by slurry coating. The slurry was produced by mixing fine nickel powder and organic-metal solution containing $8 \%$ yttrium.
After application and baking of the anode activator, a dense YSZ electrolyte was coated on it by APS, followed by sealing treatment surface. The LSH cathode was produced by flame coating, and platinum and nickel power lead were attached to the cathode and anode, respectively.

An hph-type N10 substrate tube was made in the same way. It was an inhomogeneous tube with high dense/porous/high dense distribution in the axial direction. The porous region had comparatively large mesh-1ike pores and porosity could be controlled quite easily. The fuel electrode (anode) of the $\mathrm{Ni}-20 \mathrm{YS} 2$ cermet layer was made by flame coating so as to close the large pores in the substrate as much as possible. 


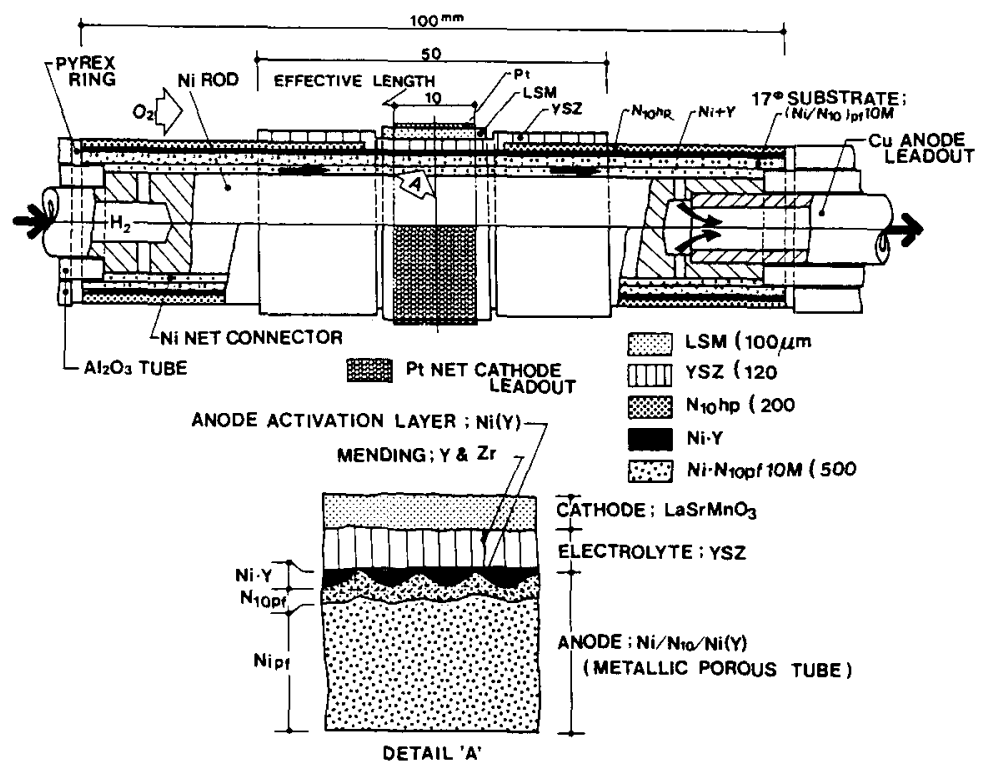

Fig. 2 Practical single cell configuration using a p-type metallic tubular substrate.

Table 2 Cell specification and typical operating conditions for long run tests.

\begin{tabular}{|c|c|c|c|c|c|c|c|c|}
\hline $\begin{array}{l}\text { TEST } \\
\text { HO. }\end{array}$ & $\begin{array}{l}\text { CELL } \\
\text { HO. }\end{array}$ & $\begin{array}{l}\text { AMODE } \\
\text { SUBSTRATE }\end{array}$ & $\begin{array}{l}\text { ANODE } \\
\text { ACTIVATOR } \\
(\mu \mathrm{m})\end{array}$ & $\begin{array}{l}\text { ELECTRO- } \\
\text { LYTE } \\
(\mu m)\end{array}$ & $\begin{array}{l}\text { CATHODE } \\
(\mu \mathrm{m})\end{array}$ & $\begin{array}{l}\text { OPERATING } \\
\text { TEKP. } \\
\text { (C) }\end{array}$ & $\begin{array}{l}\text { CURRENT } \\
\text { DENSITY } \\
\left(m A / E m^{2}\right)\end{array}$ & $\begin{array}{l}\text { DURATIOH } \\
\text { TIME } \\
\text { (hr) }\end{array}$ \\
\hline RUN-10 & 2 & $\begin{array}{l}\mathrm{P}-\mathrm{TYPE} \\
\mathrm{Ni} / \mathrm{M1O}\end{array}$ & $\begin{array}{l}\mathrm{Ni-Y} \\
(30)\end{array}$ & $\begin{array}{l}\text { TYSZ } \\
\text { (120) }\end{array}$ & (100) & 950 & $\begin{array}{l}2500 \\
300\end{array}$ & 2.100 \\
\hline RUH-14 & 1 & $\begin{array}{l}\mathrm{P}-\mathrm{TYPE} \\
\mathrm{Mi} / \mathrm{MIO}\end{array}$ & $\begin{array}{l}n i-Y \\
(30) \\
(30)\end{array}$ & $\begin{array}{l}7 Y S Z \\
(220)\end{array}$ & $\begin{array}{l}\text { LSW } \\
(100)\end{array}$ & 925 & 300 & 3.521 \\
\hline RUN-15 & 4 & $\begin{array}{l}\text { hph-TYPE } \\
\text { H10 }\end{array}$ & $\begin{array}{l}\text { Milot? YSZ2O } \\
(100)\end{array}$ & $\begin{array}{l}\text { TYSZ } \\
(105)\end{array}$ & (15U) & 925 & 200 & 4.066 \\
\hline RUN-16 & 3 & $\begin{array}{l}\text { D-TYPE } \\
\text { Ni } / \text { M10 }\end{array}$ & $\begin{array}{l}M i-Y \\
(30)\end{array}$ & $\begin{array}{l}7 Y S Z \\
(200)\end{array}$ & (150 & 925 & 400 & $\begin{array}{l}\text { OVER } \\
\text { 5. } 000\end{array}$ \\
\hline
\end{tabular}

\section{4 Test procedure}

Cell specifications are shown in Table 2.

Four single cell experiments were carried out on fuel cell test stands. The electrical load was connected to fixed resistors in RUN 10 . In RUNS 10, 15 and 16, NISTAC model NC-15P was used to keep the current constant throughout the operation. The electric circuit is shown in Fig. 3.

\section{RESULTS AND DISCUSSION}

\section{1 Cell performance}

Dry hydrogen and pure oxygen were used to conduct power generation tests. Flow rate was adjusted for optimum performance (high flow yielding low utilization), and changes in current

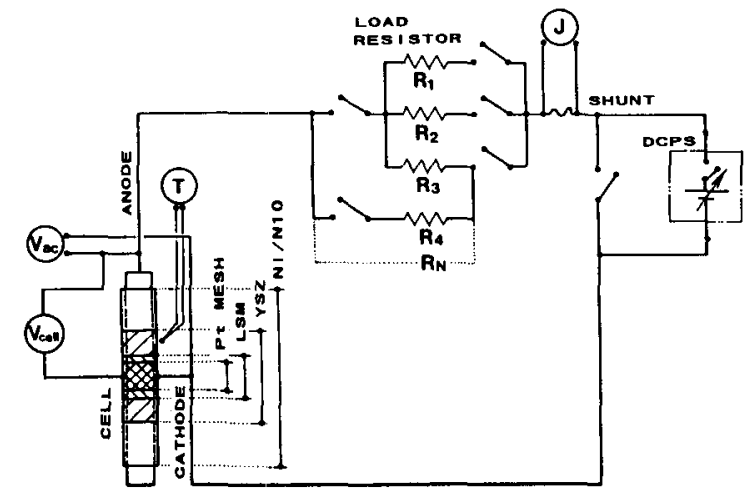

Fig. 3 An electric circuit used in single cell experiments. 
and voltage with time were noted and V-I curves at every 500 power hours were obtained. Figure 4 shows the relation between fuel utilization and fuel flow rates in RUN-16 at current density of $200 \sim 600 \mathrm{~mA} / \mathrm{cm}^{2}$ and $925^{\circ} \mathrm{C}$. The data shows that the fuel utilization rate was of the order of a few $\%$ in every test run. RUN-10 was carried out to prove the concept of introducing the metallic components at $950^{\circ} \mathrm{C}$. Running power time was 2,100 hrs. Cell behavior was monitored under a constant load of $0.4 \Omega$ since a cell voltage slightly larger than $0.8 \mathrm{~V}$. The cell $\mathrm{OCV}$ of $1.03 \mathrm{~V}$, short

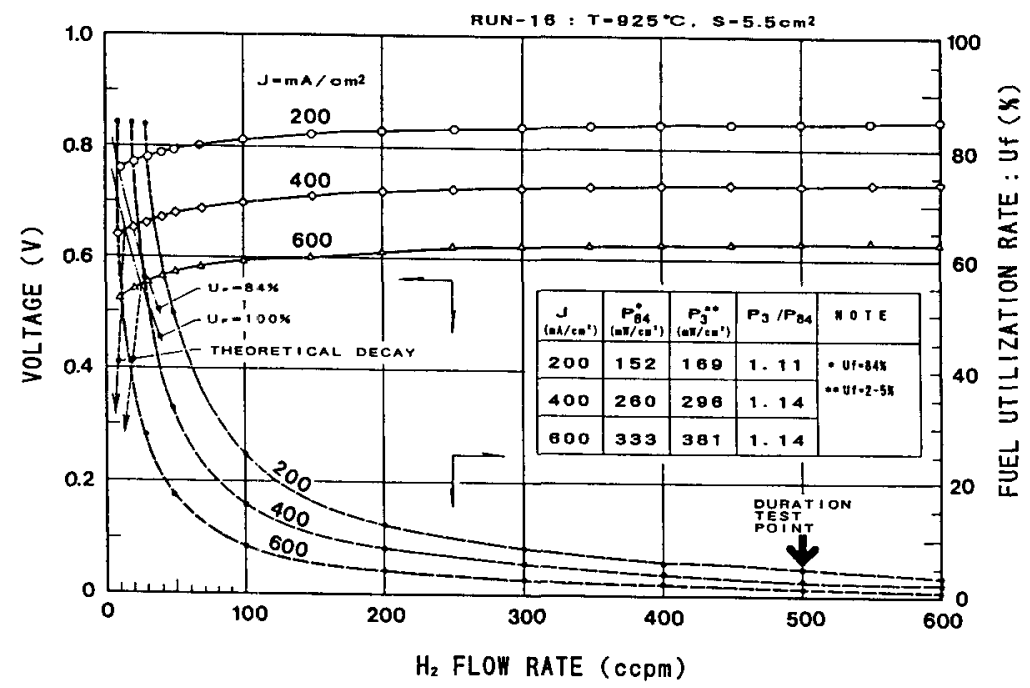

Fig. 4 Relation between fuel utilization and fuel flow rate in RUN-16 test.

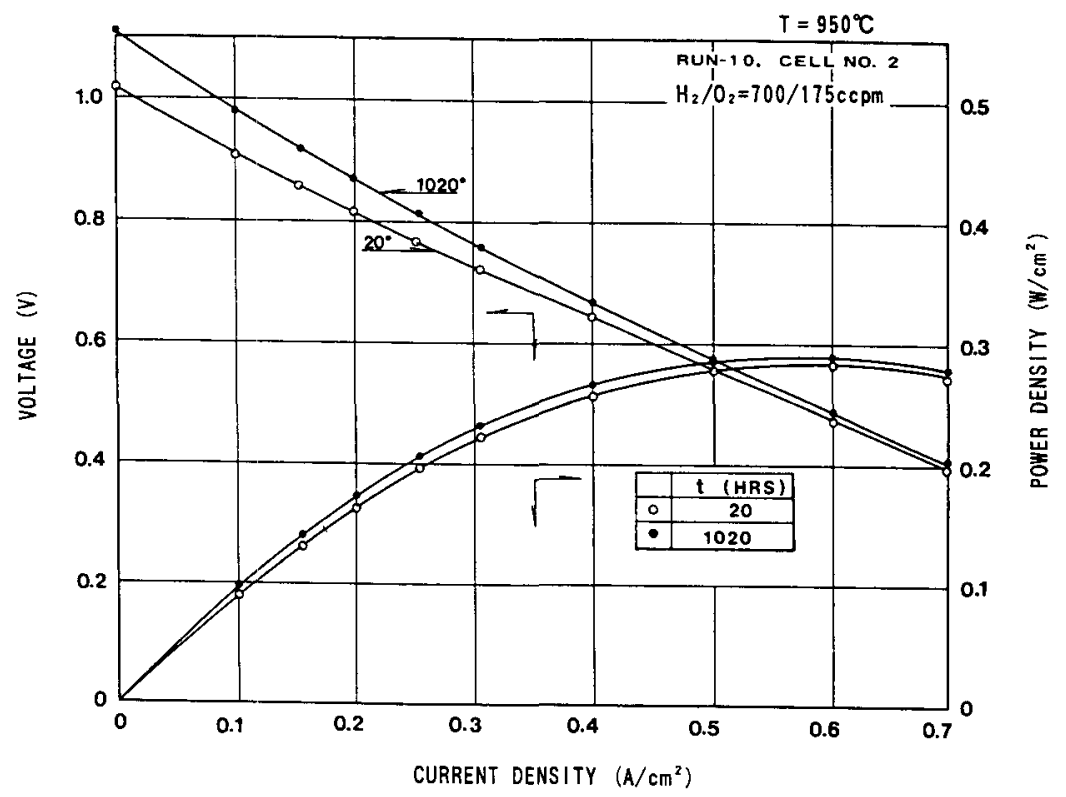

Fig. 5 Comparison of $V-1$ curves between 20 snd 1,020 hrs of running time from power start at a temperature of $950^{\circ} \mathrm{C}$. $\quad(U f=3.7 \%)$ 
circuit current of $1,150 \mathrm{~mA} / \mathrm{cm}^{2}$ and power density of $228 \mathrm{~mW} / \mathrm{cm}^{2}\left(0.7 \mathrm{~V}-325 \mathrm{mN} / \mathrm{cm}^{2}\right)$ were obtained in the first long run test. At this load, cell output steadily increased from $220 \mathrm{~mW} / \mathrm{cm}^{2}$ to $250 \mathrm{~mW}$ $/ \mathrm{cm}^{2}$ during the first $1,000 \mathrm{hrs}$. From 1,000 to 2, 100 power hrs, current and vol tage were changed to $0.84 \mathrm{~V}-370 \mathrm{~mA} / \mathrm{cm}^{2}\left(300 \mathrm{~mW} / \mathrm{cm}^{2}\right)$ by reducing the load to $0.35 \Omega$, but gradual power decrease was observed at 1,200 power hrs. Figure 5 shows $\mathrm{V}-1$ curves at 20 and 1,020 hrs of power time. To evaluate single cell performance, duration tests were conducted at constant current and $925^{\circ} \mathrm{C}$.

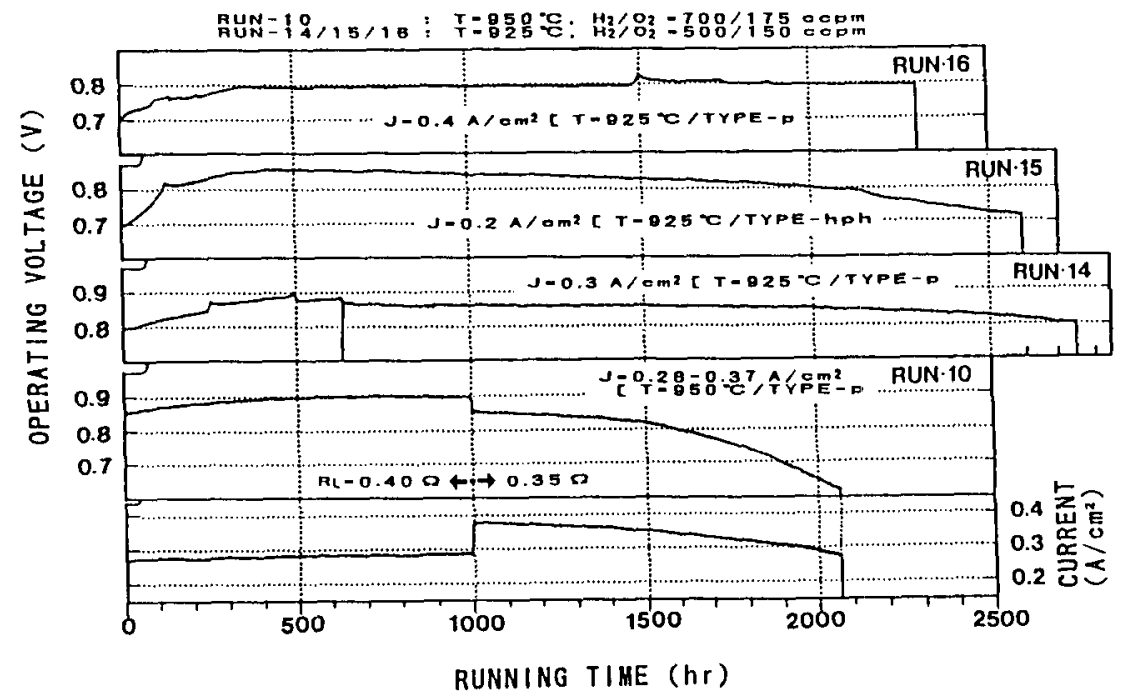

Fig. 6 Stabilities of cell operating voltage under a constant current in test RUN-14, 15 , and 16 at a temperature of $925^{\circ} \mathrm{C}$ and under a constant load in test RUN-10 at a temperature of $950^{\circ} \mathrm{C}$.

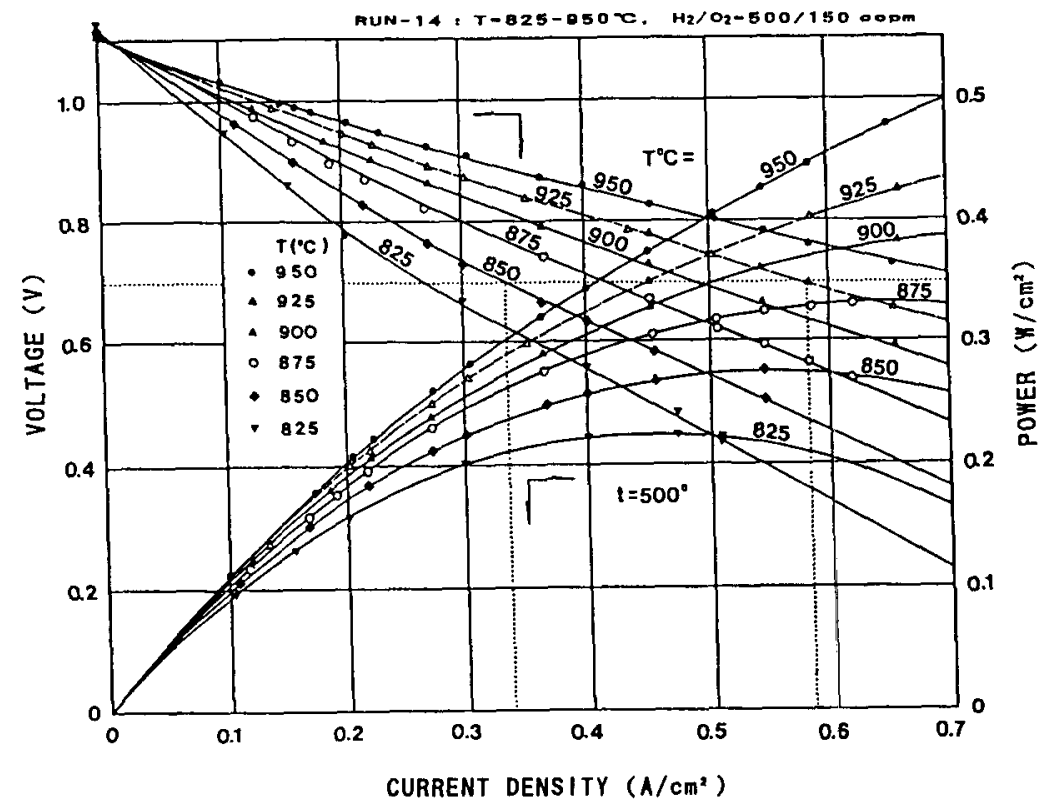

Fig. $7 V-1$ characteristics curves in a temperature range from $825 \sim 950^{\circ} \mathrm{C}$ and a power time of $500 \mathrm{hr}$. (Uf=3. $7 \mathrm{X})$ 


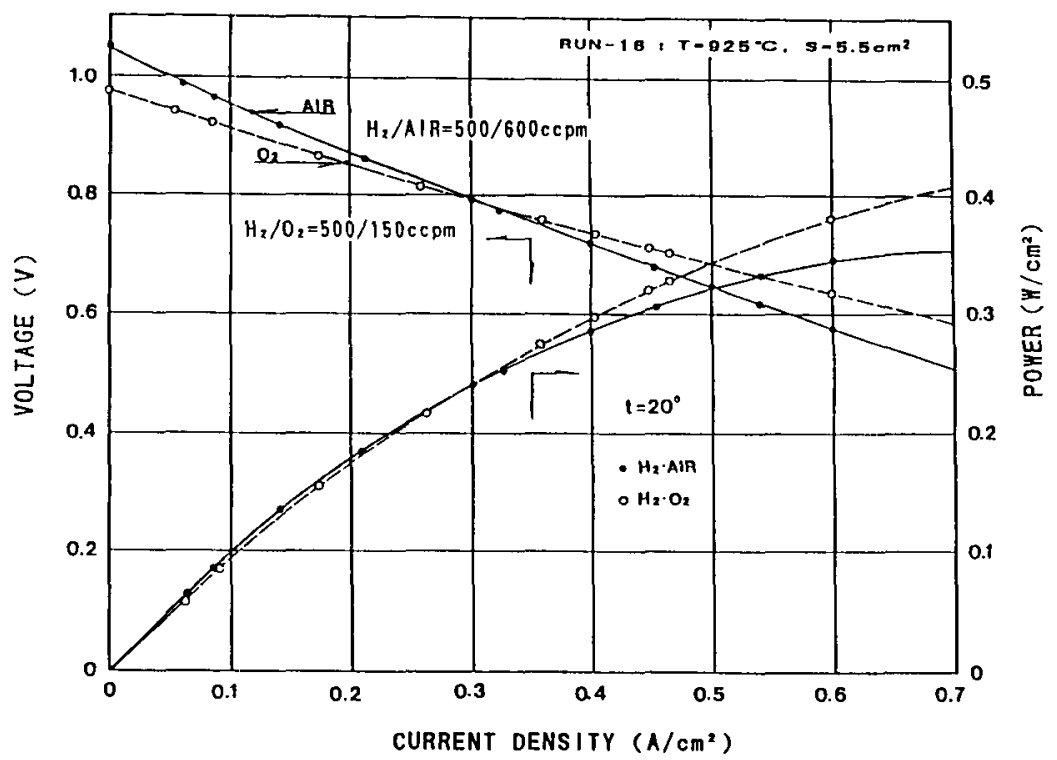

Fig. 8 Comparison of $V-1$ curves between $\mathrm{H}_{2} / \mathrm{O}_{2}$ and $\mathrm{H}_{2} / \mathrm{A} / \mathrm{R}$ at a temperature of $925^{\circ} \mathrm{C} \quad(U \mathrm{f}=3.7 \%)$.

Table 3 A summary of typical operating parameters in long duration experiments.

\begin{tabular}{|c|c|c|c|c|c|c|c|c|c|}
\hline $\begin{array}{l}\text { TEST } \\
\text { NO. }\end{array}$ & $\begin{array}{l}\text { SUBST- } \\
\text { RATE }\end{array}$ & $\begin{array}{l}\text { ANOOE } \\
\text { ACTI- } \\
\text { YATOR }\end{array}$ & $\begin{array}{l}\text { OPERA- } \\
\text { TING } \\
\text { TEMP. } \\
\text { (c) }\end{array}$ & $\begin{array}{l}\text { LOG- } \\
\text { GING } \\
\text { IIME } \\
(h r) \\
\end{array}$ & $\begin{array}{l}\text { CURRENT } \\
\text { DEXSITY } \\
\left(W A / C E^{2}\right)\end{array}$ & $\begin{array}{l}\text { OPER } \\
\text { CIRCUIT } \\
\text { YOLTAGE } \\
(V)\end{array}$ & $\begin{array}{l}\text { CELLL } \\
\text { IMPE- } \\
\text { DAKCE } \\
\left(Q \in \text { P }^{\circ}\right)\end{array}$ & $\begin{array}{l}\text { POTER } \\
\text { OUTPUT } \\
\text { AT } 0.7 Y \\
\text { (mw/ens) }\end{array}$ & $\begin{array}{l}\text { YOLTAGE } \\
\text { DEGRAE } \\
\text { DATIOK } \\
\left(X / 10^{2} \mathrm{H}\right)\end{array}$ \\
\hline RUN-10 & P & $\overline{N I-Y}$ & 850 & 2.060 & 270 & 1.16 & 2.08 & 154 & 14.62 \\
\hline RUH-14 & $D$ & $M i-\bar{r}$ & 825 & 1.865 & 300 & 1.10 & $0 . \overline{82}$ & 328 & 0.74 \\
\hline RUN-15 & hoh & $\begin{array}{l}\text { Niof } \\
\text { iYsz2O }\end{array}$ & 925 & 800 & 200 & 0.96 & 0.86 & 207 & 4.84 \\
\hline RUN-16 & $p$ & $K i-Y$ & 925 & 2.175 & 400 & 1.05 & 0.70 & 342 & 0 \\
\hline
\end{tabular}

NOTE: $H_{2} / 0_{2}=500 / 150 \mathrm{ecpm}$.

Vol tage change was monitored at current densities of $200 \mathrm{~mA} / \mathrm{cm}^{2}$ (RUN-15), $300 \mathrm{~mA} / \mathrm{cm}^{2}$ (RUN-14) and 400 $\mathrm{mA} / \mathrm{cm}^{2}$ (RUN-16), except when $V-1$ data were taken. The stability of operating voltage up to the end of the first thermal cycle is shown in Fig. 6. V-I of RUNs 14 and 16 are shown in Fig. 7 and 8 .

In RUN 14, the performance was best ; power out put values were $500 \mathrm{~m} / \mathrm{cm}^{2}\left(0.7 \mathrm{~V}-720 \mathrm{~mA} / \mathrm{cm}^{2}\right.$ at $\left.950^{\circ} \mathrm{C}\right)$ and $350 \mathrm{~m} / \mathrm{cm}^{2}\left(0.7 \mathrm{~V}-500 \mathrm{~mA} / \mathrm{cm}^{2}\right.$ at $\left.900^{\circ} \mathrm{C}\right)$. Test results are summarized in Table 3.

\section{2 Post test analysis}

Following the 2,100 hrs duration test (RUN-10). no significant damage or degradation was observed. Microscopic observation of a vertical section along the axial direction, failed to show remarkable damage. A cross-sectional structure of the YSZ layer was essentially a mono-layer, as indicated by initial microscopic observation. A sintered layer of $30 \sim 40 \mu \mathrm{m}$ close to the outerinterface was seen after the test. The sintering of YSZ caused $\mathrm{OCV}$ to increase from $1.03 \mathrm{~V}$ after power start $(20 \mathrm{hr})$ to $1.16 \mathrm{~V}$ before power termination (2,060 hr).

The EPMA analysis indicated aluninium and chromiume from the N1O substrate diffuse into the 


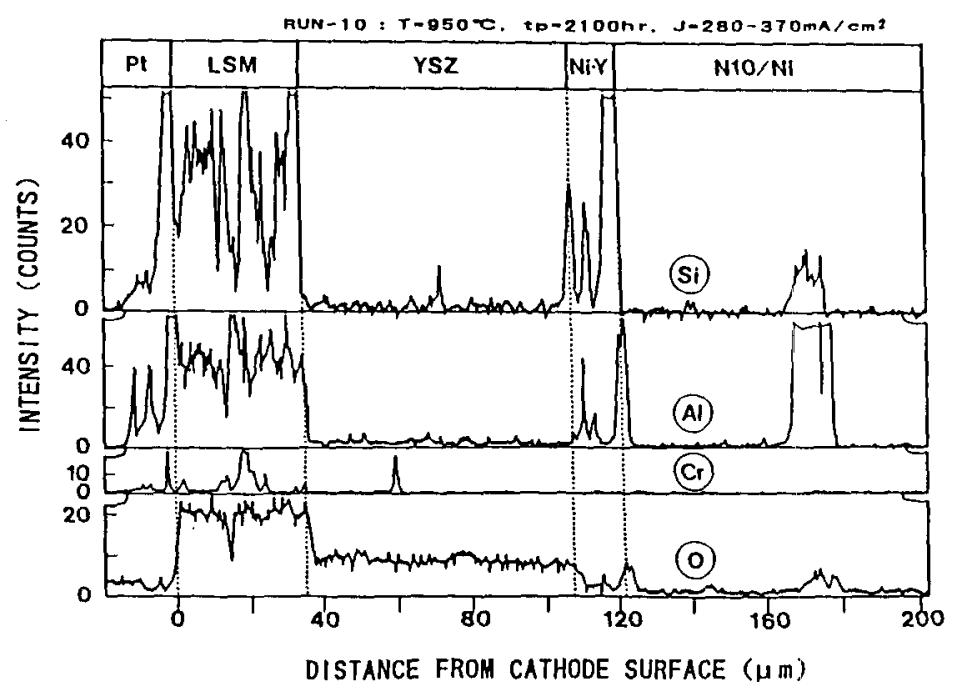

- Fig. 9 Diffusion of $\mathrm{Si}$, Al and $\mathrm{Cr}$ to cathode observed by EPMA line analysis (RUN-10).

LSH cathode across YSZ and Silicon from the pyrex sealant, at the top and bottom of the cell, accumulate and penetrate the LSH cathode layer excessively. Figure 9 shows the result of EPMA analysis for typical diffused elements in a cell section. The power degradation in RUN 10 appears to have been due to the diffusion of these elements and the formation of their oxides in the cathode layer.

Study is presentry being made to improve cell performance in regard to power stability and durability. A cell-stacking design and manufacturing conditions are being thought.

\section{CONCLUSIONS}

The authors established a new design for tubular Solid Oxide Fuel Cell using a metallic substrate and highly densified electrolyte by the chemical densification method. Even below $950^{\circ} \mathrm{C}$, the smallscale single cell (active surface area, $5.5 \mathrm{~cm}^{2}$ ) shows excellent performance. Current density is more than $300 \mathrm{~mA} / \mathrm{cm}^{2}$ at $0.7 \mathrm{~V}$ and $900^{\circ} \mathrm{C}$. Power degradation at $950^{\circ} \mathrm{C}$ may possibly be due to diffusion of silicon and aluminium.

For the present $S O F C$, the spray coating was done with the help of Nippon Coating Industry Co.,
Ltd and Onoda Cement Co., Ltd. The authors thank S. Nagata for discussion on the experiments.

Thanks are also due to Prof. T. Maruyama of TIT for his many comments on the metallurgical problems. The research in this paper was funded by the New Sunshine program of the Agency of Industrial Science and Technology.

\section{References}

1) T. J. Dollard, The Int. Fuel Cell Conf., pp313-316 (1992).

2) A. Imanaga, Y. Yamauchi, N. Hisatome, F. Umenura, Y. Ochiai, T.Saishoji, T. Muramatu and K. Utsumi, The Int. Fuel Cell Conf., pp 321-324 (1992).

3) T. Okuo, Y. Kaga, F. Uchiyama, K. Tsukamoto, A. Momma, M. Kanazawa, K. Fujii and T. Kamoshida, J, of High Temp. Society, 19, Supplement, pp 335-346 (1993).

4) T. Okuo, Y. Kaga F. Uchiyama, K. Tsukamoto, A. Momma, S. Nagata, M. Kanazawa, K. Fujii. T. Kamoshida, M. Kitho, T. Kashiwaya and S. Fukami, The 2nd Symp. on SOFC in Japan, pp49-56 (1993).

5) Y. Kaga, Y. Ohno, A. Momma, K. Tsukamoto, F. Uchiyama, and T. Okuo, T. IEEE Japan, 112-8, 8 (1992). 